\title{
TIPIFICAÇÃO DOS CRIMES CONTRA A HUMANIDADE NO BRASIL (PROJETO DE LEI 4.038/2008): É POSSÍVEL COMBATER A VIOLÊNCIA DO ESTADO ACIONANDO SEU PRÓPRIO SISTEMA PENAL?
}

\section{TIPIFICATION OF CRIMES AGAINST HUMANITY IN BRAZIL (BILL No. 4038/2008): IS IT POSSIBLE TO COMBAT THE STATE'S VIOLENCE ACTIVATING IT'S OWN CRIMINAL SYSTEM?}

\author{
${ }^{1}$ Marianny Alves \\ ${ }^{2}$ Rejane Alves de Arruda
}

\section{RESUMO}

O estudo em questão é pautado em pesquisa bibliográfica, por vezes documental, de cunho exploratório, que, ao comparar os crimes contra a humanidade previstos no Estatuto de Roma e os tipos penais previstos pelo Projeto de Lei 4.038/2008, intui questionar a viabilidade de se combater a violência do Estado acionando seu próprio sistema penal. Busca-se debater a ideia de que no sistema jurídico interno essa proposta de tipificação é incoerente, uma vez que se torna contraditório atribuir ao maior violador desta categoria de direitos a premissa de investigar e julgar crimes com os quais tem alguma relação.

Palavras-Chave: Projeto de Lei 4.038/2008; Tribunal Penal Internacional; Sistema Penal; Direitos humanos; Crimes contra a humanidade

\begin{abstract}
The study in question is based on a bibliographical research, at times documental, of an exploratory nature, that, when comparing crimes against humanity established in the Statute of Rome and the criminal offenses established in Bill No. 4.038/2008, questions the viability of combating the State's violence activating its own criminal system. The aim is to discuss the idea that this proposal of typification is incoherent in the domestic legal system, since it is contradictory to assign the greatest violator of this category of rights the premise to investigate and prosecute crimes with which it has a relationship.
\end{abstract}

Key-Words: Bill No. 4.038/2008; International Criminal Court; Criminal System; Human rights; Crimes against humanity

\footnotetext{
${ }^{1}$ Pós-graduanda stricto sensu pelo Programa de Mestrado em Direito pela Universidade Federal de Mato Grosso do Sul - UFMS, Mato Grosso do Sul (Brasil). E-mail: mariannyalves@ hotmail.com

${ }^{2}$ Doutora em Direito pela Pontifícia Universidade Católica - PUC, São Paulo (Brasil). Professora Adjunta pela Universidade Federal de Mato Grosso do Sul - UFMS, Mato Grosso do Sul (Brasil).
} 


\section{INTRODUÇÃO}

O trabalho trata de um estudo bibliográfico e documental, de caráter exploratório e minimamente comparativo, que se utilizará de método dedutivo na tentativa de alcançar os objetivos almejados. Propõe-se a discussão acerca da tipificação dos crimes contra a humanidade, em órbita internacional e nacional, para, ao final, questionar a possibilidade de contenção da violência do Estado acionando o próprio sistema penal.

Para tanto, o trabalho foi dividido em quatro tópicos, para fins meramente didáticos. No primeiro, será traçado um breve histórico acerca do processo de internacionalização dos direitos humanos, de forma a contextualizar o leitor do que se trata, de sua importância e de como se deu a conquista de direitos, hoje, denominados direitos humanos. Mais do que um apanhado de informações, intui-se convidar o leitor a entender não só a necessidade de positivação desses direitos, como também de sua efetividade.

No segundo tópico, far-se-á uma breve exposição acerca da criação do Tribunal Penal Internacional e o Estatuto de Roma. Será relatado em qual contexto o TPI se constituiu, quais suas competências, levando em consideração a matéria, o tempo, a pessoa e o território. Serão abordados, também, os crimes previstos pelo Estatuto de Roma, de forma a evidenciar o quão necessário foi a constituição de um tribunal permanente.

O terceiro tópico, por sua vez, tratará, especificamente, dos crimes contra a humanidade, objeto de estudo deste trabalho. Serão apontadas quais condutas se encontram descritas nos crimes contra a humanidade previstas no Estatuto de Roma, contrapondo-as uma a uma com o Projeto de Lei n. 4.038/2008, que pretende a tipificação dos crimes contra a humanidade em âmbito nacional.

No quarto e último tópico tem-se a pretensão de instigar o leitor a reflexão sobre a (in)efetividade e incoerência de se tipificar os crimes contra a humanidade em órbita interna como medida de contenção da violência do Estado, dado o ideal de propositura de tais crimes pelo direito internacional, não desprezando, obviamente, a nítida evolução das relações internacionais ante as tipificações.

No mais, o trabalho se justifica a fim de instigar olhares críticos acerca da temática, uma vez que as discussões jurídicas não podem se restringir à mera constatação da positivação da norma. 


\section{BREVE CONTEXTUALIZAÇÃO DO PROCESSO DE INTERNACIONALIZAÇÃO DOS DIREITOS HUMANOS}

De início, cabe esclarecer que traçar um panorama acerca do processo de internacionalização dos direitos humanos requer que se mencione o já conhecido embate sobre o conceito de direitos humanos e suas diversas distorções propagadas pela maioria dos meios de comunicação - grande responsável pelo caráter popularmente pejorativo atribuído a expressão - e mesmo por parte da academia - por vezes equivocada, mal intencionada ou de abordagem pouco comprometida.

A título de esclarecimento, os direitos humanos não dizem respeito a direitos atribuídos a uma minoria como medida compensatória, uma seleção de privilégios atribuídos a quem a sociedade não reconhece moralmente como detentores de direitos. Trata-se, sim, de um ideal a ser perseguido acerca da concretização de direitos mínimos e fundamentais capazes de satisfazer a premissa de contemplação da dignidade humana. São direitos historicamente construídos e atribuídos a todos, sem distinção, pelo simples fato de serem humanos e, por isso, detentores de direitos e dignidade. (LAFER, 2009)

Posto isso, cabe mencionar que as discussões sobre a natureza dos direitos humanos divergem em teorias protagonizadas por naturalistas e positivistas - uma discussão infindável. De antemão, o que se pode dizer é que a complexidade de um sistema "de" e "em" direitos humanos não se sustenta e não pode ter sua abordagem reduzida a apenas uma teoria, o que seria insuficiente para explicar e viabilizar sua concretização.

Assim, quanto à origem dos direitos humanos, o estudo adota a concepção de Bobbio (2004), que atribui uma origem histórica a esses direitos, vistos como naturais, por serem intrínsecos ao ser humano antes mesmo de qualquer positivação, construídos a partir de lutas por conquista de direitos, desenvolvendo-se como direitos positivos, que ainda pleiteiam efetividade, uma vez que sua contemplação são se dá por mera positivação.

Em conformidade com tal pensamento, o desafio ao qual se propõe o sistema de direitos humanos, hoje, não se refere às positivações, que são constantes e por isso satisfatórias, mas à proteção desses direitos, que só alcançariam sua efetividade, como mencionado, a partir de mecanismos de políticas públicas que assim os promovam. Afinal, os avanços em direitos humanos não se dão apenas pela órbita jurídica, mas, principal e necessariamente, pela política. 
No que tange aos antecedentes históricos que representem a internacionalização dos direitos humanos, aponta-se que o primeiro documento histórico que concebe uma ideia universal seja a Declaração dos Direitos do Homem e do Cidadão, de 1789, promulgada na França como resultado das lutas por direitos travadas em meio a Revolução Francesa. Inclusive, entende-se que a expressão "do homem” fazia referência a todos os cidadãos do mundo e não só ao povo francês. (COMPARATO, 2010)

É claro que há outros documentos situados mais ou menos no mesmo período histórico de tal Declaração que também foram muito importantes. A Declaração de Direitos do Bom Povo de Virgínea, por exemplo, promulgada em 1776; a Declaração de Independência dos Estados Unidos da América (1776) e, posteriormente, a Constituição Norte-Americana (1787) e, ainda, a Constituição de Weimar (1919), na Alemanha. (CASTRO, 2014)

Anterior a essas revoluções, menciona-se, ainda, em face da tamanha inovação, a Carta de direitos Bill of Rigths de 1215, na Inglaterra. Embora modestas suas contribuições à título de internacionalização, já tentava limitar o poder da monarquia sobre os cidadãos de seu país (CASTRO, 2014). O que ficou estabelecido após essas conquistas de direitos oriundas das revoluções modernas, mais do que um Estado de Direito, foi um Estado Liberal de Direitos, que daria impulso à propagação dos direitos considerados humanos a nível internacional.

Embora o Estado Liberal limitasse a atuação do próprio Estado ante aos cidadãos, declarava a soberania estatal a nível internacional, o que, entre outros motivos, desencadearia a Primeira Guerra Mundial (1914 -1918). Nota-se que a ideia de soberania está atrelada às duas grandes guerras mundiais e, já após a primeira, foi possível verificar a necessidade de regulamentação de um direito internacional humanitário.

Ao final da referida guerra, então, destaca-se o surgimento de documentos e acontecimentos tais como a Convenção de Genebra (1864), a fundação da Comissão Internacional da Cruz Vermelha (1863), a Convenção de Haia (1889), a fundação da Sociedade das Nações ou Liga das Nações (1919), a Organização Internacional do Trabalho (1919) e a Convenção de Genebra (1929) (COMPARATO, 2010). Nesse período já emerge a ideia e se pode falar em Direito Humanitário (PIOVESAN, 2007).

Nesse contexto, embora seja necessário apontar consideráveis evoluções no que tange aos mecanismos jurídicos e políticos, que se demonstraram ao menos atenciosos com as questões internacionais humanitárias, foi apenas após a Segunda Guerra Mundial (1945) que se pôde evidenciar o grande movimento de internacionalização de direitos. Assim, foi possível constatar a quais caminhos levavam a ideia de absoluta soberania estatal e o potencial destrutivo 
da humanidade, que já não podia esperar por maiores regulamentações, como bem coloca Piovesan:

\begin{abstract}
No momento em que os seres humanos se tornam supérfluos e descartáveis, no momento em que vige a lógica da destruição, em que cruelmente se abole o valor da pessoa humana, torna-se necessária a reconstrução dos direitos humanos, como paradigma ético capaz de restaurar a lógica do razoável. A barbárie do totalitarismo significou a ruptura do paradigma dos direitos humanos, por meio da negação do valor da pessoa humana como valor fonte do direito. Diante dessa ruptura, emerge a necessidade de reconstruir os direitos humanos, como referencial e paradigma ético que aproxime o direito da moral. Nesse cenário, o maior direito passa a ser, adotando a terminologia de Hannah Arendt, o direito a ter direitos, ou seja, o direito a ser sujeito de direitos. Nesse contexto, desenha-se o esforço de reconstrução dos direitos humanos, como paradigma e referencial ético a orientar a ordem internacional contemporânea. Se a Segunda Guerra significou a ruptura com os direitos humanos, o pós-guerra deveria significar sua reconstrução. (2007, p.118)
\end{abstract}

Ante tal contexto, em 1945, foi criada a Organização das Nações Unidas (ONU), que ficaria responsável pela tentativa de promoção da paz e da segurança internacional. O órgão objetivou instaurar regras de conduta nas relações internacionais, com ênfase na proteção dos direitos humanos. Dessa forma, o processo de internacionalização dos direitos humanos teria começado na segunda metade do século XIX e só iria se concretizar a partir da criação da ONU. É na carta da ONU, por exemplo, que se declara, pela primeira vez na história dos direitos humanos, a proibição da guerra como forma legítima de solução de conflitos. (PIOVESAN, 2007)

Ainda nesse mesmo ano, criou-se um tribunal ad hoc, conhecido como Tribunal de Nuremberg, designado para investigar e julgar os atos cometidos durante a Segunda Guerra. Assim, embora não houvesse uma legislação criminal prévia, com base nos costumes internacionais, o tribunal condenou as atrocidades nazistas, que, retroativamente, configuraram crime, por sua relevância ante a humanidade.

Em face da necessidade, iniciou-se então a redação da Declaração Universal dos Direitos Humanos, proclamada em 1948, diante da aprovação de 48 Estados, com 8 abstenções. Ficou estabelecido, assim, um rol de direitos inerentes ao homem pela simples condição humana, afirmando a compreensão comum destes direitos pelas nações como o primeiro passo ao seu pleno cumprimento. (PIOVESAN, 2007)

É preciso esclarecer que, após a Declaração Universal dos Direitos Humanos, muitas convenções foram promulgadas, trazendo um caráter vinculativo ao cumprimento da Declaração. Foram estabelecidos, ainda, mecanismos de proteção aos direitos humanos a nível global, regional e mesmo temático. Hoje o direito internacional já dispõe do Tribunal Penal 
Internacional (1998) e da possibilidade de tribunais ad hoc para o julgamento de violações de direitos humanos. (PIOVESAN, 2007)

\section{CONSIDERAÇÕES SOBRE O TRIBUNAL PENAL INTERNACIONAL}

As atrocidades cometidas durante a Segunda Guerra Mundial desencadearam o surgimento de medidas e instrumentos jurídicos importantes. No âmbito penal, destacam-se os tribunais de Nuremberg e de Tóquio, que se destinaram ao julgamento dos crimes contra paz, de guerra e contra a humanidade. De acordo com Laffer (2009), tal fato estabeleceu a premissa de que existem algumas exigências fundamentais na sociedade internacional e que a violação dessas regras enseja configuração de crime internacional.

Desde já, cabe esclarecer que a ONU dispõe de diversos órgãos que a ela se submetem para fim de fiscalização e promoção dos direitos humanos e também para punição em caso de violação de direitos, que não poderão, por limite didático, ser aqui expostos. Assim, elegeu-se importante tratar, para melhor abordagem sobre os crimes contra a humanidade, de forma mais enfática, sobre o Tribunal Penal Internacional (1998) e o Estatuto que o rege.

De acordo com os ensinamentos de Piovesan (2007), é possível afirmar que a Convenção para a Prevenção e Repressão do Crime de Genocídio (1948) seja o tratado pioneiro quanto a proteção de direitos humanos aprovado pela ONU. Desde a adoção dessa Convenção, já era prevista a criação de uma Corte Penal Internacional, que só viria a se concretizar cinquenta anos depois, com a aprovação de um Estatuto da Corte Penal Internacional.

Por razões políticas relacionadas à Guerra Fria (1947 - 1991), o planejamento de criação de um tribunal penal internacional e de regulamentação dos crimes internacionais foi adiado na ocasião. Mas, no início da década de noventa, o assunto voltou à tona e a Assembleia Geral da ONU recomendou, à Comissão de Direito Internacional, a elaboração de um estatuto que amparasse a existência de um tribunal internacional permanente. Essa criação foi acelerada em face do estabelecimento de novos tribunais ad hoc para julgamento de crimes cometidos na ex-Ioguslávia (1993) e em Ruanda (1994). (PIOVESAN, 2007)

A necessidade de criação de um tribunal permanente se justificava devido às críticas direcionadas aos tribunais ad hoc até então estabelecidos. O próprio Tribunal de Nuremberg, embora registrado como marco histórico, entre outras coisas, afrontou o princípio da legalidade na seara penal, quando puniu agentes por crimes que não estavam previamente estabelecidos. Sem contar que a composição para julgamento nos tribunais ad hoc obedeciam a interesses 
políticos, sendo comum que o violador fosse julgado pelos próprios violados ou por seus inimigos políticos.

Dessa forma, após um processo de elaboração e ajustes, no ano de 1998, em uma conferência em Roma, foi aprovado o estatuto que regulamentaria o Tribunal Penal Internacional, definindo os crimes de genocídio, contra a humanidade, os de guerra, e deixando prevista futura conceituação do crime de agressão. Nesse mesmo ano, ocorreu a primeira condenação pelo crime de genocídio por meio do Tribunal Internacional, devido ao massacre ocorrido em Ruanda no ano de 1994, o que evidenciava ainda mais a necessidade de criação e regulamentação do TPI. (JAPIASSÚ, 2004)

No ano de 2002, finalmente, o Estatuto de Roma entrou em vigor, cessando muitas das críticas sobre legalidade e esclarecendo aquilo que o costume internacional e os tribunais ad hoc já estavam colocando em prática. É importante mencionar também que o Tribunal foi criado, principalmente, como meio de proteção da população civil contra aquele que se demonstrou grande violador de direitos: o Estado, sendo ele omisso, enquanto tinha o dever de atuação. (PIOVESAN, 2007)

Nesse sentido, o TPI é criado como um mecanismo de jurisdição complementar, de forma que não retira dos Estados a legitimidade primária em atuar na investigação e a punição dos tipos ali previstos. Sua atuação dar-se-á nas hipóteses de omissão dos Estados. Sua competência ainda pode ser definida em razão da matéria, uma vez estabelecidos os crimes no Estatuto de Roma; em razão da pessoa, haja vista a previsão de punição de pessoa física com idade mínima de 18 anos; em razão do território, tendo como requisito sua atuação quando envolve um estado-parte; e temporal, afinal só exercerá jurisdição em relação aos crimes praticados após sua entrada em vigor. (LIMA, 2006)

No que tange aos crimes ali definidos, evidencia-se sua exclusividade àqueles considerados graves, que afetariam a comunidade internacional como um todo, o que é afirmado no artigo $5^{\circ}$ do Estatuto (BRASIL, 2002). O primeiro deles, o crime de genocídio, também considerado um crime contra a humanidade, ganha autonomia de um tipo penal desconexo do rol de crimes contra a humanidade, tratado mais à frente, devido a sua relevância. Trata-se, segundo o artigo $6^{\circ}$ do Estatuto, do homicídio, ofensa grave à integridade física, sujeição intencional, impedimento de reprodução ou transferência, praticados com a intenção de destruir, no todo ou em parte, grupo nacional, étnico, racial ou religioso.

Os crimes de guerra, por sua vez, tratados no artigo $8^{\circ}$, dizem respeito às violações graves ao que foi previsto na Convenção de Genebra de 1949, violações aos costumes e leis 
que regulamentam os conflitos armados, ambos verificados em contexto internacional ou nacional. Trata-se de uma série de atos exaustivamente descritos ao longo do artigo, quando cometidos como parte integrante de um plano, política ou prática em larga escala, que aconteçam, necessariamente, em um contexto de conflito armado. (FERNANDES, 2006)

O crime de agressão, como mencionado anteriormente, embora componha o rol de crimes previstos no Estatuto de Roma, ainda não possui definição, haja vista a falta de consenso sobre sua tipificação durante a criação do Estatuto. Importante esclarecer que, embora não disponha de definição, sua inclusão no rol já aponta um aspecto positivo, uma vez que sua exclusão significaria retrocesso na trajetória dos direitos internacionais. (LIMA, 2006)

Por fim, os crimes contra a humanidade previstos no Estatuto de Roma serão objeto do item seguinte do presente trabalho, justificado pelo fato de se propor uma análise mais significativa sobre eles.

\section{OS CRIMES CONTRA A HUMANIDADE: ESTATUTO DE ROMA X PROJETO DE LEI No 4.038/2008}

Diferente do crime de genocídio, que havia sido pouco abordado, e do crime de agressão, que ainda espera por definição, os crimes contra a humanidade não são de definição recente nos documentos internacionais. Consta que a expressão foi utilizada pela primeira vez em 1915, em um comunicado feito pela Grã-Bretanha, França e Rússia, fazendo referência aos atos cometidos pela Turquia contra a Armênia. (LIMA, 2006)

De acordo com Bierrebach (2011, p.179), "os crimes contra a humanidade são, possivelmente, o tipo penal que mais provoca mal-entendidos no direito criminal internacional. Isso ocorre pela irregularidade com que a expressão tem sido utilizada, seja no âmbito acadêmico, seja entre legisladores e juízes". Corriqueiramente, remete-se aos crimes contra a humanidade sempre que há graves violações de direitos humanos, mas tal referência se faz pouco pertinente.

Os crimes contra a humanidade teriam sido tipificados pela primeira vez em 1945, na Declaração de Londres, utilizada pelos Tribunais Internacionais Militares para julgarem os crimes cometidos na Segunda Guerra, mas seu conceito estava atrelado aos crimes de guerra e aos crimes contra a paz, sendo que, assim, só seriam julgados em contexto de conflito armado, o que os colocava em uma categoria complementar de crimes. (LIMA, 2006) 
Mais tarde, quando se retira do conceito o requisito do conflito armado, os crimes contra a humanidade ganham autonomia, sendo utilizados nos julgamentos dos tribunais ad hoc para a ex-Iuguslávia e para Ruanda, passando a compor, posteriormente, o Estatuto de Roma (BRASIL, 2002), que elenca, em seu artigo $7^{\circ}$, parágrafo $1^{\circ}$, onze tipos penais considerados graves - ou seja, o suficiente para compor um rol de crimes contra a humanidade, quais sejam:

a) Homicídio; b) Extermínio; c) Escravidão; d) Deportação ou transferência forçada de uma população; e) Prisão ou outra forma de privação da liberdade física grave, em violação das normas fundamentais de direito internacional; f) Tortura; g) Agressão sexual, escravatura sexual, prostituição forçada, gravidez forçada, esterilização forçada ou qualquer outra forma de violência no campo sexual de gravidade comparável; h) Perseguição de um grupo ou coletividade que possa ser identificado, por motivos políticos, raciais, nacionais, étnicos, culturais, religiosos ou de gênero, tal como definido no parágrafo $3^{\circ}$, ou em função de outros critérios universalmente reconhecidos como inaceitáveis no direito internacional, relacionados com qualquer ato referido neste parágrafo ou com qualquer crime da competência do Tribunal; i) Desaparecimento forçado de pessoas; j) Crime de apartheid; k) Outros atos desumanos de caráter semelhante, que causem intencionalmente grande sofrimento, ou afetem gravemente a integridade física ou a saúde física ou mental.

Ao se analisar tal rol, percebe-se a estreita relação que a tipificação possui com a proteção dos direitos humanos na sua forma mais clara. De acordo com o que foi estabelecido no caput, trata-se de crime contra a humanidade qualquer um dos atos descritos quando em contexto de ataque generalizado ou sistemático, contra população civil, com a premissa de que haja conhecimento acerca desse ataque.

As penas aplicáveis aos crimes contra a humanidade obedecem às disposições gerais do Estatuto, que são aplicáveis a qualquer dos crimes ali previstos, não havendo uma cominação exata de pena por tipo penal. O Estatuto prevê, em seu artigo 77, a possibilidade de aplicação de pena de prisão, com um limite máximo de 30 anos, ou de prisão perpétua, caso haja justificativa para tal, ou uma pena de multa, ou mesmo a perda de bens, produtos, e demais objetos provenientes do crime.

No Brasil, o Estatuto foi contemplado por meio do Decreto ${ }^{\circ} 4.388$ de 2002, e, embora a Constituição Federal (BRASIL, 1988) preveja em seu artigo $5^{\circ}$, LXXVIII, parágrafos $3^{\circ}$ e $4^{\circ}$, a submissão do Estado ao Tribunal Penal Internacional e o status de emenda constitucional aos tratados e convenções internacionais sobre direitos humanos, existe em trâmite no Congresso um Projeto de Lei que objetiva a criminalização das condutas tipificadas pelo direito internacional em órbita interna.

O Projeto de Lei $\mathrm{n}^{\circ}$ 4.038, de 2008, de autoria do Poder Executivo, no geral, dispõe sobre o crime de genocídio, define os crimes contra a humanidade, os crimes de guerra e os crimes contra a administração da justiça do Tribunal Penal Internacional. Em alguns 
dispositivos, reproduz na íntegra a redação do Estatuto de Roma, em outros, limita ou abrange os tipos penais, de forma a alterar o entendimento que tem o TPI acerca dos crimes, o que geraria algumas contradições no julgamento de tais crimes, uma vez que o país aderiu ao Estatuto de Roma.

No que tange aos crimes contra a humanidade, foco deste estudo, tentar-se-á fazer, minimamente, uma análise comparativa entre o Estatuto de Roma e a tipificação apresentada no Projeto de Lei $\mathrm{n}^{\circ} 4.038$, com o intuito de esclarecer em quais pontos se correspondem e em quais divergem. Será adotado, como referencial para sequência de abordagem, o Estatuto de Roma. A começar pelo caput que, como mencionado, define requisitos para que a conduta seja definida como crime contra a humanidade. No artigo 17, do PL 4.038, não se inclui a premissa de que haja conhecimento sobre os ataques, como estabelece o Estatuto de Roma.

No que tange ao crime de homicídio, previsto pelo Estatuto em seu artigo $7^{\circ}$, parágrafo $1^{\circ}$, alínea $a$, encontra seu correspondente no PL 4.038 no artigo 18 , que define o fato pela conduta "matar". Embora exista óbvia relação entre homicídio e matar alguém, o substantivo homicídio se refere a matar alguém ou causar sua morte, enquanto que a previsão no PL é mais restrita. Há que se mencionar, ainda, que a previsão de pena do PL para esse tipo é de 12 a 30 anos de reclusão.

No que se refere ao extermínio, o Estatuto de Roma dispõe de uma explicação acerca do tipo, encontrada no parágrafo $2^{\circ}$, alínea $b$, determinando que "compreende a sujeição intencional a condições de vida, tais como a privação do acesso a alimentos ou medicamentos, com vista a causar a destruição de uma parte da população" (BRASIL, 2002). No Projeto de Lei, recorre-se novamente ao verbo matar e apresenta apenas o dolo, não estabelecendo de forma clara questões como privação de acesso a alimentos ou medicamentos. A pena prevista para esse tipo é de 20 a 30 anos de reclusão.

Sobre a escravidão, o Estatuto também recorre a uma explicação disposta no parágrafo $2^{\circ}$, alínea $c$, do mesmo artigo, que explica a necessidade de que se mantenha sobre a vítima o mesmo domínio que se tem sobre propriedade, no todo ou em parte, abrangendo à condição servil, que se equipararia a escravidão para fins de punição e dando especial atenção à crianças e mulheres. Em relação à duração das penas, se encontram em uma mesma média.

O PL aborda a questão em seu artigo 20, utilizando-se, no geral, do que foi estabelecido no Estatuto, mas não abrangendo, ao menos de forma clara, a condição servil, e não priorizando crianças e mulheres. Outra diferença está no acréscimo de um parágrafo único que prevê a incursão nas mesmas penas do tráfico de pessoas, o que também já seria implicitamente 
abrangido pelo Estatuto, e o tráfico de órgãos humanos, o que parece ser uma novidade. Estabelece-se, ainda, como sanção para a prática do crime, uma pena de 5 a 15 anos de reclusão.

Por deportação ou transferência forçada de população, entende-se, segundo o parágrafo $2^{\circ}$, alínea $d$, do mesmo artigo do Estatuto, o deslocamento forçado de pessoas sem motivo reconhecido pelo direito internacional que justifique tal ato. No Projeto de Lei, há um enunciado pouco mais simplificado, mas que não altera a interpretação idêntica da qual se faz pelo Estatuto. No que tange às penas, o PL prevê entre 5 e 15 anos de reclusão, inferior à previsão do Estatuto.

Referente à prisão ou outra forma de privação de liberdade física grave, previsto no Estatuto de Roma, constitui um requisito para seu enquadramento que haja a violação de preceitos fundamentais de direito internacional, mas o Estatuto não optou por esclarecer a conduta no parágrafo $2^{\circ}$, como, em regra, fez com outros tipos. O Projeto de Lei, por sua vez no artigo 22, especifica as condutas "determinar, executar ou manter" como uma medida privativa de liberdade, em desacordo com os preceitos de direito internacional. A pena tem previsão de 4 a 12 anos.

A tortura, definida pelo parágrafo $2^{\circ}$, alínea $e$, ainda no artigo $7^{\circ}$ do Estatuto, é entendida como ato capaz de promover intencionalmente sofrimento, físico ou mental, àquele que está sob custódia ou controle do acusado. O dispositivo ainda exclui de enquadramento os atos relacionados a sanção penal condenatória.

O PL dispõe prevê o crime de tortura em seu artigo 23, parágrafo $1^{\circ}$, e se utiliza do mesmo entendimento previsto no Estatuto para enquadramento da conduta. No parágrafo $2^{\circ}$ do mesmo artigo, institui qualificadora, no caso de resultar morte sem o dolo para tanto; e no artigo 24, paralelamente, trata dos tratamentos degradantes ou desumanos, ofendendo dignidade ou decoro, ainda na condição de custódia ou controle do autor. As penas previstas pela PL são, respectivamente, de 5 a 15 anos; de 10 a 30 anos; e de 14 a 12 anos de reclusão.

O tipo previsto na alínea $g$, parágrafo $1^{\circ}$ do artigo $7^{\circ}$ do Estatuto, diz respeito a crimes sexuais. Trata o dispositivo dos atos de agressão, escravatura, prostituição forçada, gravidez forçada, esterilização forçada, ou qualquer outra violência grave, mas com viés sexual. No seu parágrafo $2^{\circ}$ explica-se apenas o conceito de gravidez forçada, que consiste na privação de liberdade de mulher engravidada a força, para fins de interferir na composição étnica de uma população.

O Projeto de Lei prevê, em seu artigo 25, a agressão sexual, na forma que a doutrina entende por estupro; no parágrafo único traz-se a previsão da qualificadora, se o resultado da 
agressão for morte e o agente não tiver dolo para tal. No artigo seguinte, o PL ainda prevê crime contra a humanidade por ato obsceno e, no artigo 27 , a presença forçada em ato obsceno. As penas são, respectivamente, de 5 a 15 anos, de 10 a 30 anos e de 4 a 12 anos, sendo as duas últimas, de reclusão.

Ainda sobre os crimes sexuais, o Projeto ainda dispõe sobre escravidão sexual no artigo 28; prostituição forçada, no artigo, 29; gravidez forçada, no artigo 30 - e aqui o crime não está vinculado à privação de liberdade, como no Estatuto de Roma -; a esterilização forçada, no artigo 31. A penas são, respectivamente, de 10 a 15 anos, de 10 a 20 anos, de 6 a 12 anos, e de 4 a 8 anos de reclusão. Nota-se que muitas das condutas são de exclusividade do PL, não tendo como fundamento o Estatuto de Roma.

A perseguição, tratada pelo Estatuto na alínea $h$, parágrafo $1^{\circ}$ do artigo $7^{\circ}$, tem complementação no parágrafo $2^{\circ}$, alínea $g$ do mesmo artigo. Preceitua que a perseguição diz respeito à privação intencional e grave de direitos fundamentais por motivos de identidade de grupo ou coletividade em causa. Seu correspondente no Projeto do Lei está localizado no artigo 32, que não se utiliza da palavra perseguição, mencionando a privação de direitos pelos motivos já elencados no Estatuto. A pena prevista pelo PL está entre 4 e 8 anos de reclusão.

O desaparecimento forçado possui complementariedade no parágrafo $2^{\circ}$, alínea $i$, do artigo que dispõe sobre os crimes contra a humanidade no Estatuto de Roma, sendo considerado desaparecimento forçado a detenção, a prisão ou o sequestro de pessoas, seguido da recusa de se reconhecer o motivo da prisão ou de lhe negar o direito de comunicação à terceiros sobre sua localização durante longo prazo. Também é um requisito que a ação seja praticada em nome, com autorização, apoio ou sob o conhecimento do Estado ou de organização política.

No Projeto de Lei n. 4.038, o desaparecimento forçado é previsto no artigo 33 e, além da previsão parecida com a do Estatuto, prevê-se que o prazo longo seja traduzido por período superior a 48 horas. Outra diferença está no parágrafo $1^{\circ}$ do mesmo artigo que traz novas condutas que também se enquadram no desaparecimento forçado, quais sejam: ordenar, manter sob guarda, custódia ou vigilância pessoa que se encontra na situação de vítima de tal crime. Dispõe, ainda, em seu parágrafo $2^{\circ}$, que a morte não encerra a prática do crime, sendo que ele perdura enquanto não seja esclarecido o paradeiro da vítima. A pena prevista é de 5 a 15 anos e o há o alerta de que o crime pode ser aplicado em concorrência com outros crimes.

O crime de apartheid se complementa nas explicações dadas pelo parágrafo $2^{\circ}$, alínea $h$, e diz respeito a qualquer ato desumano praticado num contex to de regime institucionalizado de opressão e domínio de um grupo racial sobre outro(s). O projeto de lei, por sua vez, dispõe 
que o crime de apartheid se refere à prática de qualquer um dos atos descritos no título de crimes contra a humanidade, num contexto de regime institucionalizado de opressão de um grupo racial sobre outro. Prevê a pena de 4 a 12 anos de reclusão.

A última tipificação dos crimes contra a humanidade no Estatuto de Roma faz referência a outros atos desumanos que causem sofrimento ou afetem gravemente a integridade ou saúde física ou mental. Não dispõe de maiores explicações sobre os atos ali incluídos, o que deixa o dispositivo aberto para uma ampla interpretação. O PL 4.038, por outro lado, relaciona o referido dispositivo com seu artigo 35, tipificando o crime de lesão corporal, de forma simples e prevendo uma qualificadora no parágrafo único, no caso da lesão resultar em morte, sem dolo para tal. As penas são de 4 a 8 anos no caso simples e de 8 a 16 de reclusão no ato qualificado.

Embora o Estatuto de Roma não disponha mais de tipificações sobre os crimes contra a humanidade, além das mencionadas, o Projeto de Lei 4.038 ainda prevê a conduta de associação para a prática de crimes contra a humanidade, com requisito mínimo da participação de três pessoas, prevendo uma pena de reclusão de 5 a 15 anos.

Como foi possível notar, quanto às tipificações, algumas diferenças são significativas, enquanto alguns dispositivos do Projeto de Lei são meras cópias das disposições do Estatuto de Roma. As penas previstas pelo PL, por outro lado, são, em regra, inferiores àquelas previstas pelo Estatuto, sendo que, em nenhum momento, o PL menciona a possibilidade de pena perpétua, uma vez que tal previsão seria inviável no Brasil ante a proibição explícita no artigo $5^{\circ}$, inciso XLVI, alínea $b$, da Constituição Federal (BRASIL, 1988).

\section{NOTAS SOBRE A POSSIBILIDADE DE SE COMBATER A VIOLENCIA DO ESTADO ACIONANDO O SEU SISTEMA PENAL.}

O processo de criminalização no âmbito internacional, principalmente a concretização do Tribunal Penal Internacional, figura o que o autor Silva Sánchez (2013) conceituou como a quarta velocidade do direito penal. São ideais neopunitivistas relativos aos crimes que devido a sua gravidade afetam a comunidade internacional. Para esses crimes, afirma a teoria, admitese um direito penal intervencionista, capaz de punir com rigidez, ultrapassando marcos de legalidade, como ocorreu no Tribunal de Nuremberg, ou restringindo garantias individuais.

O direito penal que se sustenta na quarta velocidade é marcado por uma aplicação não pautada em direitos humanos para defender bens jurídicos de importância ímpar, justamente 
por serem intrínsecos à concepção de direitos humanos, o que parece um tanto contraditório. Renova-se, com esse ideal, a crença de que o direito penal deve permear todas as áreas sociais, inclusive o âmbito internacional, antes caracterizado por se pautar em soluções mais políticas do que jurídicas.

Defende-se aqui, com ressalvas ao que ultrapassa os limites penais mínimos, que o processo de criminalização no direito internacional foi necessário, haja vista sua atuação como mecanismo de contenção das guerras, regulamentando os conflitos e tornando suas soluções institucionalizadas. Afinal, nas palavras de Zaffaroni:

[...] Se não houvesse uma legislação internacional que forçasse a imposição dessas penas e a reparação e que, em última instância e suplementarmente, tomasse a seu cargo a imposição das penas e da reparação, a lei internacional seria um mera declaração de bons propósitos, uma simples solicitação para que crimes em massa não sejam mais cometidos a partir do poder. [...] Um número bastante significativo de Estados decidiu submeter esta competência supletiva ou complementar a um tribunal internacional, o que tem a vantagem de diminuir a anarquia que um uso indiscriminado e maciço do princípio universal poderia gerar. (2007, p.182)

Essa concepção descrita por Silva Sánchez, contudo, geralmente justificada porque os crimes ali envolvidos são de grande escala, proporcional a órbita universal, pelo que se tenta instaurar, nas esferas nacionais, como é o caso da proposta do Projeto de Lei 4.038/2008, já exposto. Nota-se que, embora as penas previstas no PL sejam inferiores às do Estatuto e condizentes com a previsão nacional, elas demonstram um aumento significativo das penas previstas pelas leis penais brasileiras, novas tipificações e a projeção mais atuante do Estado quanto à punição.

No Brasil, não muito diferente de outros países, há uma grande propensão à expansão do sistema penal que, superficialmente, é vista como benéfica, não sendo preciso grandes esforços para verificar tal premissa. Afinal, quando o cidadão comum lê as notícias diárias e nelas vislumbra a aprovação ou entrada em vigor de um novo tipo penal ou de punição mais rígida para um crime já existente costuma encarar a novidade com um ar de conquista, como se ali houvesse a possibilidade de diminuição da violência, uma vez que o poder punitivo se expandiu.

A proposta encanta até mesmo os movimentos sociais, que ao lutarem por suas conquistas de direitos, rotineiramente, incluem em suas pautas o pedido de criminalização de alguma conduta ou mesmo a mudança de pena para uma mais rígida. Tais situações, admita-se, atribuem ao Direito Penal um poder potencialmente pretensioso, haja vista o depósito de expectativas de que as ações reprováveis sejam diminuídas porque a elas foi atribuída ou intensificada uma sanção. 
Há que se mencionar, no entanto, uma contradição muito relevante no intuito de tipificação nacional dos crimes contra a humanidade: atribuir ao maior violador de direitos humanos a prerrogativa de investigar e punir os crimes por ele ou sob seu conhecimento praticados. De acordo com os ensinamentos de Zaffaroni (2007), o poder punitivo só pode ser exercido sobre quem não detém esse poder, estando o Estado responsável pela punição, por óbvio que os mesmos poderes usados para cometerem tais violações seriam usados para se protegerem.

Destarte, é conveniente ressaltar que diz respeito às atribuições do Estado a promoção e proteção dos direitos humanos. Mudar seu foco de promotor e garantidor dos direitos humanos para aplicador das sanções penais na hipótese de violação é, senão, uma tática para disfarçar sua ausência na política em direitos humanos. A fragilidade política é, frequentemente, disfarçada pelo controle penal. (ANDRADE, 2012)

\section{CONSIDERAÇÕES FINAIS}

À guisa de considerações finais, tentou-se demonstrar que a tipificação dos crimes contra a humanidade em âmbito interno não se trata de uma boa ideia, uma vez que se estaria dando, ao maior violador de direitos, a função de investigar e julgas os crimes que, de certa forma, mesmo não sendo de sua autoria, o envolve.

Nas partes iniciais do texto, foi demonstrado que os direitos humanos não constituem apenas um rol de direitos estabelecidos em âmbito internacional, sendo o resultado de um processo histórico, um ideal a ser alcançado, que ainda pleiteia efetivação, e que para alcançálo não requer apenas movimentos do meio jurídico, mas principalmente no campo político, o que faz a temática de direitos humanos ser necessariamente interdisciplinar.

Posteriormente, ao tratar do Tribunal Penal Internacional, demonstrou-se a necessidade histórica e política de sua criação e verificou-se sob quais requisitos o Tribunal atua, sendo, por isso, considerado uma instância que institucionalizou os conflitos internacionais mais graves, permitindo que a vingança privada deixasse de ser uma possibilidade entre as nações.

O estudo apresentou, ainda, o rol de crimes contra a humanidade, definido pelo Estatuto de Roma, demonstrando suas diferenças e semelhanças com os dispositivos do Projeto de Lei $n^{\circ} 4.038 / 2008$, que ainda se encontra em trâmite de aprovação no sistema legislativo brasileiro. 
Com isso, restou evidente que, embora o Projeto, no geral, possua penas e abordagens mais brandas que as previstas no Estatuto de Roma, possui um viés mais punitivista do que aquele teoricamente utilizado pelo país.

No mais, tentou-se demonstrar que o Estado não tem legitimidade penal, fundada em direitos humanos, para tratar da questão dos crimes contra a humanidade em órbita interna, sendo essa, por ora, uma tentativa frustrada de ampliar seu sistema punitivo, prometendo aos entes internacionais maior atenção às violações de direitos humanos, de forma a disfarçar sua pouca atuação na promoção e proteção destes.

Por fim, ressalta-se que não houve o intuito de esgotar a discussão, mas, apenas, colocar em dúvida as reais intenções dos processos de criminalização, uma vez que não se confia no sistema penal para solução de conflitos que não lhe pertencem, sendo esta uma violação ao princípio da ultima ratio, no qual deveriam se pautar as questões penais.

\section{REFERÊNCIAS}

ANDRADE, Vera Regina de. Pelas mãos da criminologia: o controle penal para além da (des)ilusão. Rio de Janeiro: Revan, 2012.

BIERRENBACH, Ana Maria. O conceito de responsabilidade de proteger e o Direito Internacional Humanitário. Brasília: Fundação Alexandre Gusmão, 2011.

BITTAR, Eduardo Carlos Bianca; ALMEIDA, Guilherme Assis de. Curso de Filosofia do Direito. 8. ed. São Paulo: Atlas, 2010.

BOBBIO, Norberto. A era dos direitos. Rio de Janeiro: Elsevier, 2004.

BRASIL. Casa Civil. Constituição da República Federativa do Brasil de 1988.

Disponível em: http://www.planalto.gov.br/ccivil_03/constituicao/constituicao.htm Acesso em: 17 jun. 2016.

Casa Civil. Decreto no 4.388 de 2002. Promulga o Estatuto de Roma do Tribunal Penal Internacional. Disponível em: http://www.planalto.gov.br/ccivil_03/decreto/2002/D4388.htm Acesso em: 17 jun. 2016.

Subchefia de Assuntos Parlamentares. Projeto de Lei no 4.038 de 2008. Dispõe sobre o crime de genocídio, define os crimes contra a humanidade, os crimes de guerra e os crimes contra a administração da justiça do Tribunal Penal Internacional, institui normas processuais específicas, dispõe sobre a cooperação com o Tribunal Penal Internacional, e dá outras providências. Disponível em:

http://www.planalto.gov.br/ccivil_03/projetos/PL/2008/msg700-080917.htm Acesso em: 17 jun. 2016. 
CASTRO, Flávia Lages de. História do Direito: Geral e Brasil. 10. ed. Rio de Janeiro: Lumen Juris, 2014.

COMPARATO, Fábio Konder. A afirmação histórica dos direitos humanos. 7. ed. São Paulo: Saraiva, 2010.

FERNANDES, David Augusto. Tribunal Penal Internacional: a concretização de um sonho. Rio de Janeiro: Renovar, 2006.

JAPIASSÚ, Carlos Eduardo Adriano. O Tribunal Penal Internacional: a internacionalização do Direito Penal. Rio de Janeiro: Lumen Juris, 2004.

LAFER, Celso. A reconstrução dos direitos humanos: um diálogo com o pensamento de Hanna Arendt. São Paulo: Companhia das Letras, 2009.

LIMA, Renata Mantovani de; BRINA, Marina Martins da Costa. O Tribunal Penal Internacional. Belo Horizonte: Del Rey Ltda, 2006.

PIOVESAN, Flávia. Direitos humanos e o direito constitucional internacional. 8. ed. São Paulo: Saraiva, 2007.

SILVA SÁNCHEZ, Jesús-Maria. A expansão do Direito Penal: aspectos da política criminal nas sociedades pós-industriais. 3. ed. rev. e atual. São Paulo: Editora Revista dos Tribunais, 2013.

ZAFFARONI, Eugenio Raul. O inimigo no direito penal. 2. ed. Rio de Janeiro: Revan, 2007. 